\title{
Jadids Movement in Central Asia in the Late 19th and the Early 20th Centuries
}

\author{
Kanat Bazarbayev ${ }^{1} \&$ Adilbekova Zabirash Ashimkhanovna ${ }^{1}$ \\ ${ }^{1}$ International Kazakh-Turkish University, Republic of Kazakhstan \\ Correspondence: Kanat Bazarbayev, International Kazakh-Turkish University, Republic of Kazakhstan. E-mail: \\ kanat-08@mail.ru
}

Received: October 15, $2011 \quad$ Accepted: April 9, $2012 \quad$ Published: July 1, 2012

doi:10.5539/ass.v8n8p225

URL: http://dx.doi.org/10.5539/ass.v8n8p225

\begin{abstract}
The article deals with the history of national-progressive movement of the late $19^{\text {th }}$ and early $20^{\text {th }}$ centuries which is called "Jadidism". The history of Jadidism and its evolution from enlightenment to powerful political movement are retraced in the article.

Jadidism is considered as the phenomenal public occurence in the history. It arouse in the depth of the Central Asian society on the basis of a harmonious combination of a rich spiritual heritage and as realization of its place in realities of that time and the necessity of its reforming for successful prosperity in the future.

Now, there appears the possibility of restoring the historical truth in the conditions of profound changes in the historical science. The need for resolute revision of former aims about role and place in historical process of national-progressive movement has ripened as the unique social and political phenomenon in the early $20^{\text {th }}$ century. This phenomenon promoted a national consciousness growth and is of the essence in formation and development of national-liberation ideology, in struggle for independence.
\end{abstract}

Keywords: Central Asia, Jadidism, national progressionist, Turkestan, Muslims

\section{Introduction}

In the late 19th and the early 20th century Uzbekistan became a center of arousing enlightening movement known as "Jadid" which means "new". It is possible to consider Jadidism as one of the branches and types of reformatory movement of the national-progressive intellectuals in Central Asia which had arisen and had been developing in many countries of the East in the late 19th and the early 20th centuries. The term "Jadid" came into existence from the concept "usul-and-Jadid" ("a new method") which included new methods of teaching per European samples. Later, as the extension of Jadid movement's taks, the content of the term has also been extended. Along with enlightenment Jadids aspired to change the old system of social and political statuses to progressive forms of development. The progressive national intellectuals of Turkestan, realizing its political and economic backwardness from the developed world that caused to become Russia's colony; a prime task was to educate people. Trying to unite the best achievements of culture of the East and the West, they defined two main goals: to raise the standard of people's living to the level of highly-educated people and establish a national-democratic country in Turkestan. Uzbekistan became a center of Jadid movement which was headed by an inhabitant of Tashkent, an eminent public and political figure, journalist and teacher, Munavvar Kary Abdurashidkhanov along with Mahmudkhodjha Bekhbudy. The features of intellectual world outlook of the progressive-minded people are characterized, besides their views and attitudes to history, culture, religion and statehood are studied in the movement history periodization.

\section{Reasons of Occurence and the First Problem}

The entry of Uzbekistan upon the path of sovereign development provoked a sharp public interest to history, especially to the past gone not too far, events in the early 20th century when in Turkestan the political events have touched upon all social strata of society. The movement of national progressionists known Jadidism entered the public arena as the leader. Within the Soviet decades its history was sunk into to oblivion or was wittingly falsified (Pyaskovski, 1958 ). 
Now because of domestic scientists' efforts, new essential approaches to this problem have been affirmed. Now it is obvious that Jadids'movement expressed the most progressive direction in a complex tangle of political forces of Turkestan society in the 19th and early 20th centuries. It was based on the world humanistic and national values that shaped the long felt needs of social development and vital concerns of indigenous population of the krai.

Jadidism has gone through a difficult way of development in dynamics from enlightenment up to a powerful political movement. A serious economic position of the broad masses caused by an imperial policy and local despotism, precarious lag from economically developed countries of the world, cultural regress, stagnation of thoughts induced Jadids to seek for effective means for crisis overcoming.

The Turkestan krai of that time represented the Russian Empire' colony which has become its raw appendage, gratuitously supplying a mother country with its natural resources, particularly with cotton and silk. Later, an extraction program of other natural resources and their driving to the Center has been worked out and only sectors serving these purposes were developed. The Russian capital's appearance in Turkestan provided a stimulus to banks development, railways constructions etc. But the development of the usurious capital appreciably increased the number of broken peasants. By November ' 12 the indebtedness of the population to the credit unions had amounted to 157 million roubles that led to the increase of landless peasants. By 1917 the number of landless peasants accounts for 30 percent in some districts of Fergana region, 40-50 percent in Tashkent and Andizhan regions of all sectors.

During the First World War over 59 million poods of cotton, 8,5 million poods of cottonseed oil, 950 thousand poods of silk cocoons, 2925 thousand poods of wool were exported from Turkestan kray (National Economy of Turkestan, 1918) and 70 thousand horses, over 12 thousand camels etc. were sent to Russia (Red Archive, Moscow, 1929, p. 54).

On the other hand, the new European culture with a sufficient experience and technological innovations, developed education system which is connected with the European world entered here. And, of course, it could not help influencing on progressively thinking intellects of the kray. At this conjuncture it was obvious that a major cause of social and colonial oppression, backwardness of the country in ignorance and the illiteracy of nation supported by ruling circles. Therefore problem solving was seen only through enlightenment.

Why the question was put in this way? Because Jadids or as they called themselves national progressionists were highly educated people of that time. They studied, taught and aspired to master as Eastern so Occidental cultures, visited Russia, European and Asian countries. They could observe, compare a development level of education and culture in the various countries and, being intellectuals and had a dream to spread the world civilization achievements in Turkestan.

Enlightenment in Turkestan had deep genetic roots. Strengthening of education philosophy in the 19th century was associated with the objective reasons of backwardness of the Central Asian khanates in connection with weakening of the Great silk way role in the 16th century, opening of shipping routes and rapid technological progress of European countries in the 18-19th centuries. The subjective reasons were domestic wars doing harm to a national economy and general development. After the Russian Empire conquest of Turkestan, opportunities for penetration of democratic ideas opened up from Europe and Asia and dialogue with the world promoted a development of emancipation ideas in the region. İt was the first steps in forming national freedom philosophy whose main postulate was an enlightenment. Its supporters were far from heading, organizing or supporting popular uprisings that would break out in different corners of the region, but they were well aware of their causes and their critical attitude to an existing system and understanding the necessity of reforms was a big achievement of that time.

Passionate supporters of reforms who urged people to knowledge and education in their verses were an outstanding enlightener as Akhmad Donish, poets Mukimi, Furkat, Hamza Berdah, Zavki, Bayoni, Avaz Utar. Democratic ideas reigned over the minds of such outstanding figures, as Abai Kunanbayev, Shokan Valikhanov who saw a daylight not only in enlightenment, but also in unity of Turkic nations. Jadids who have gone far ahead from the predecessors, from enlightenment to policy grew up on this ground.

In forming a new philosophy of reform and enlightment a certain pride of place must be given to Akhmad Donish whose full name was Akhmad Ibn Mir Nassir Ibn Yusuf Al-Hanafi As Siddiki al-Bukhari (1827-1897), a person of encyclopedic knowledge. Contemporaries named him "mukhandis" ("engineer") for his deep knowledge in natural and exact sciences. He carried out researches on astronomy and cosmology and was good at philosophy, history, literature, musical art and calligraphy. His philosophical conclusions had the strongest influence on society which were based not only on knowledge of the history of statehood and philosophy of this question, but also on practical experience about how the state is supposed to be. 
Political, social and philosophical views of Akhmad Donish have found the most complete reflection in his work "Navodir ul-vakoe" ("Rare incidents") (Note1) (Historigraphy of social sciences in Uzbekstan, 1974. p.164).

As Egyptian reformists of that time, he was opposed to fatalism, considering that one should act actively to improve his status and not to be in waiting position. In his opinion, the state had been established not to satisfy the interests of group of people and vice versa people's interests and its leaders are supposed to care of well-being of nations and societies. One of his positions laid the groundwork for Jadids doctrine i.e. to follow progressive countries' example, irrespective of religious and national identities of nation.

Thus, Jadid movement was formed on educational ideas of the national-progressive intellectuals of Central Asia which had a wide spectrum of problems directed to the development of society.

It is possible to consider Jadidism as one of the branches and variants of reformatory movement of the national-progressive intellectuals in Central Asia which had arisen and has been developing in many countries of the East in the19th and the early 20th centuries. The term "Jadid" came into existence from the concept "usul-i-dzhadid" ("a new method") which also included new methods of training per European samples.

Later, as the extension of Jadid movement's taks, the content of the term has also been extended. Along with enlightenment Jadids aspired to change the old system of social and political statuses to progressive forms of development. But it was the second stage of movement. In Turkestan the greatest representatives of this movement were Makhmud-Khodja Bekhbudi, Ubaidullah Assadullahodjaev, Munavvar kary Abdurashidhanov, Abdulla Avloni, Tashpulatbek Norbutayev, Khodja Muin, Abdukadyr Shakuri, Nasyrkhantura Komolkhonturayev, Obidzhon Mahmudov, Ashurali Zakhiri, Ishankhodja Khanhodjayev, Iskhakhan Tura Ibrat; In Bukhara Sadriddin Aini, Faizulla Khodjayev, Abdurauf Fitrat, Musa Saidzhanov, Abdulvahid Burhanov, Usman Khodjayev, Mirkomil Burkhanov, Mukhitdin Rafoat, Mukhitdin Mansurov, Mukhtor Saidzhanov, Abdukadyr Mukhitdinov and others and in Khiva Bobookhun Salimov, Palvanniyaz Khodja Yusupov, Avaz Utar, Khusain Matmurodov, Nazar Sholikorov, Otazhon Abdalov, Khudoibergan Divanov, Muhammad Rasul Mirzo, Matyakub Pozachi, Otazhon Sadayev, Bekzhon Rakhimov, Muhammad Devanzade and others. All of them made a huge contribution not only to enlightenment of the broad masses, but also to the development of emancipating ideas.

Jadidism was developed step-by-step. Starting with the idea of enlightenment which progressionists considered a universal panacea changed a vector of its direction and found wider range of action. After two decades, Jadids realized that political changes were required to overcome economic and cultural stagnation. However, at an enlightenment stage progressionists saw the primary goal in creation of a new education system and all forces were given to realize this reform.

What is the phenomenon of Jadidism? First of all, the phenomenon of it lies in extremely highly developed intelligence being knowledgeable of East so European cultures. Nearly all of them having higher religious education and being brought up on poetry of A.Navoi, A.Dzhami, M.Fizuli, philosophical treatises of medieval east thinkers, enriched it with the achievements of foreign culture as East so European. It defined the features of Jadid philosophical outlook that reflected in their activity on education reform and enlighment in tote.

Jadids proved theoretically not only the necessity of its realization, but it also made much efforts for education realization in practice, opening new method schools, libraries, reading rooms and publishing textbooks and newspapers and creating the first theater.

For the first time Jadid schools were opened in 1898 in Kokand under the control of Salokhuddin domla and in 1899 the idea of opening schools were backed by Mannon kary in Tashkent and in Andidjan by Shamsiddin domla.

By 1911 the number of new method schools in Turkestan was 63 with 4106 children; Fergana region had 30 schools, 12 in Semireche and Dzhetisu (also Dzhetysu; from Kazakh zheti ["seven"] and su ["water"]), the south-east part of the Kazakh SSR, located between the Lake Balkhash in the north, lakes Sasykol and Alakol in the northeast, the Dzungarian Alatau in the south-east, and the northern Tien-Shan mountain in the south and 5 schools in Samarkand. Certainly, Tashkent was differed with considerable quantity and quality of schools training, there were 24 schools (Hudaikulov, 1995, p.78).

Of course, it is impossible to compare these schools with the European standards schools though they were approximated to this type not only by disciplines and school furniture, but also by teaching methods. Unlike old maktabs (school) children were able to read and write within 40 days here. Therefore in a short space of time these schools found trust and popularity among the population. Besides teachers were, basically, young men whose ages were under 25 years and a "baculine method" of teaching was out of the question. Firstly, there were many teachers of Tatar nationality among them. 
Later, administration of tzar was afraid that the ideas of "Pan-Turkism" and "Pan-Islamism" may be disseminated and forbad to teach at schools. A.Khudaikulov making a careful study of this issue said that exemplary new method schools were the school of Dzhurabayev and A.Shakuri in Samarkand; the school of Abdul Vakhab in Fergana, the school of Mazitov in Beshkovak settlement of Fergana region; the school of Ishankhodja Khankhodjayev in Tashkent, the school of Sabirdzhan Rakhimov and Munavvar kary Abdurashidkhanov. The local authorities considered the school of Munavvar kary the best one. At that time the school-leavers of this school were M.Uigun, Hamza, K.Ramazan and Oibek.

It should be noted these schools had a peculiarity that they depated from the Arabic-Persian direction and lessons were conducted, basically, in Uzbek and Tadjik languages. But in some of them the Russian language was taught. The innovators of these schools were A.Shakuri and Munavvar kary. The coeducation of boys and girls at some schools especially in Tashkent can be considered a big advancement. It was really revolutionary step if one takes into account the population' religiousness.

Firstly, at schools the lessons were conducted on the grounds of Russian particularly, Tatar textbooks. But later, teachers realizing that the lessons were to be conducted in a native language started writing textbooks. M.Bekhbudi and Munavvar kary Abdurashidkhanov wrote over 15 educational studies and textbooks (Central state Archive of the Republic of Uzbekstan, 955 document, p.230).

Tzar administration of Turkestan firstly took a positive view of the activity of new method schools realizing that they provide a certain level of general knowledge in comparison with old maktabs. However with the course of time the trend to organize and popularize new method schools was not encouraged and even led to the closing of some of them. The authorities discovered an inculcation of abilities to Muslim children to "the perception of all sorts of tendencies" i.e. antigovernment moods in them. N.P. Ostroumov, a national schools inspector of Turkestan general governorship played a leading part in determination of this policy. As A.Khudaikulov wrote, the authorities' negative attitude towards new schools "was dictated by fear of national consciousness development of indigenous population. Therefore they hindered the development and distribution of Jadid schools in every possible way. By specified reasons the rate was staked on politically reliable, but ineffective old method maktabs of confessional type that do not meet the requirements of the time and which were under the complete control of "Kadimists" - for the most part a conservatively-minded clergy who were absolutely not interested in strengthening the influence of the new method system of education".

Finally, the confrontation of Kadimists and Jadids to each other was conveniet for tzar administration. Nevertheless, Jadids kept achieving the opening of new schools in exchange of closed. As a result of it by 1917 there were about 100 schools in Turkestan (Central state Archive of the Republic of Uzbekstan, 955 document, p.230).

Renovationist processes in the education system also spread in the Bukhara Emirate and the Khiva khanate. The first new method school with the Tadjik language teaching was opened by Abdulvakhid Munzim in Bukhara in 1908. However, the confrontation of the conservatively-minded clergy was stronger and effective that quite often led to schools destruction by a crowd of mullahs. The school of A.Munzima was aslo destroyed. Being afraid of severe reprisal he left Karshi. S.Aini, a passionate initiator of Jadid schools, hid at friends' for three weeks (Gafarov, 2000, p.73).

As a result of it in 1909 A.Munzim's school was closed and people of Bukhara were not allowed to send the children to even Tatar new method schools. However a new school had already "made much noise" and people kept sending their children to the school. According to S.Aini when the number of children reached 50, they were put to a Tatar school near Gavkushan madrasah.

Early in December, 1910, Jadids of Bukhara organized a secret society "Tarbiyai-atfol" ("Education of children") dealt with the opening of primary illegal new method schools. In 1911-1912 about 57 schools operated in the Bukhara Emirate (Bendrikov 1960, p.260).

The best schools among them were the schools of Mukomil Burkhanov, Usmankhodja Pulatkhodjayev, Khalidkhodji Mekhri (1913). At Mullah Vafo's school in Bukhara much attention was paid to the study of the Russian language.

A new method education was also spread in other cities of the emirate such as Karshi, Shahrisyabz, Karakul and Gizhduvan. But in July, 1914, under the influence of the upper clergy of Bukhara and with political agency's approval and by the order of emir Alimkhan they were closed. In the mind of the population, especially the intellectuals, the efficiency concept of new method schools was already created, therefore, in spite of interdictions, their quantity started to increase. "Views of liberals and a new method of teaching took roots among high classes of Bukhara" (Zenkovsкy, 1967. p.88). Therefore their children kept taking lessons from Jadid teachers. The 
anonymous appeal of the merchants to the Political agency in July, 1914 making the request to support in opening of schools is demonstrative. It runs as follows: “... new method schools, where our children in a short space of time learnt reading and writing, by the order of His Majesty the Emir under the complaint of 2-3 mullahs, were closed. About one month time has passed as our children have not gone to school and roam about the streets. It is well-known to you that we, Bukhara nationals, are mostly merchants and handicraftsmen and there are not so many literate people among us and owing to this fact it is rather desirable for us if our children would be able to read and write quickly and maintain our trading records and accounts. We used to go to old method schools within 7-8 years but remained illiterate and got no benefit from them. Therefore we kindly request you to reopen the closed schools" (Klimovich, 1936. pp.214-215).

Similar letters did not cause any reactions from the authorities. But nevertheless, despite severe constraints in which Jadid schools existed, they have done, perhaps, the most important thing i.e they moved the population's consciousness from the outdated fixed notions towards the open world.

In Khiva khanate the problem of reforming the education system would solve much easier. It depended on the fact that Khiva khan Muhammad Rakhim II (Feruz) was an outstanding supporter of culture who entirely approved of innovations. In 1874 on his initiative a lithographic machine was brought to Khiva from Russia (Kayumov, 2005. p.15). Opening of new method schools in khanate faced no resistance of the authorities in Bukhara. Feruz supported the organization of schools and many high officials followed the lead of him.

In 1906 by his permission the school for girls was opened in Urgench which he visited and familiarized with its works (Polvanov, 2005, p.15). Moreover, an eager activity on education reform was carried out by a khanate's chief vizier Islom Khodja, known for his progressive positions and who backed Jadids movement in Khiva.

Owing of the efforts of Khiva enlighteners and heads of movement including Bobookhun Salimov, P.Yusupov new schools were opened in New Urgench, Kungrad, Gurlen and Shavat. In many respects the idea of opening schools was supported by the society "Jamiyati Khairiya" who raised funds to open new method schools. B.Salimov toghether with B.Rakhimov worked out the first reading books designed for primary schools.

Trying to establish the new system of education and enlightenment, national progressionists leaned on cultural heritage of the people of Central Asia. They quite often reminded their readers about it in their works mentioning Ibn Sina, Farabi, Ulugbek as actual founders of social and scientific reforms in Central Asia. According to Jadids, the study of their works can advance progressive development of the kray and raise national consciousness of the nation. The crucial issue that had defined the world outlook paradigms of Jadidism was the theme "the West-East". Jadids were inclined to draw conclusions about historical links of Central Asia with the West Europe, focusing them on the present. Propagandizing an education, they quite often remembered the European medieval Renaissance, realizing that the reasons for development of European powers was the education system and development of new technologies. They did their best to introduce any technology into the educational reforms which was acceptable to Turkestan.

At achievement of progress in Turkestan, Jadids gave much attention on the economy development, however they set the development of a national press and public education above it. One of the progressionists wrote: "Without the national press there is no nation" (Rizobadli, 1915, p.4).

The integration of progressive forces of the kray and activization of Jadids' educational activity was marked not only by opening of new method schools, but also by organizing national press including new newspapers and magazines appearance. So, in 1906 under the editorship of I.Obidov the newspaper "Tarakkiy", that year the newspaper "Hurshid" edited by Munavvar kary, in 1907-1908 the newspaper "Shukhrat" under the direction of A.Avloni commenced to be published and A.Bektemirov was assigned to head an editorial staff of the newspaper "Osiyo". However shortly after the colonial government relying on the report of their expert N.P. Ostroumov, closed these editions. On the basis of a new wave of enlightenment in 1913-1915 such newspapers and magazines as "Samarkand", "Sadoi Turkiston", "Sadoi Fargona", "El bairogi”, "Kengash", "Turon" and "Oina” and in 1917 "Hurriyat", "Nazhot", "Kengash", "Turon", "Ulug Turkiston" and other publications were appeared. Due to the help of businessman Saidkarim Saidazimbayev the newspaper "Tuzhzhor" came out, which becoming a mouthpiece of Jadids, opened up large-scale possibilities to propagandize their reformatory ideas than schools. They were over 15 in total and it was a big ideological power. The range was very wide from educational up to political ones. The national press that started to be formed has clearly demonstrated that a new type of man with progressive thinking and who is concerned about the welfare of the nation has appeared.

In a number of reasons that hindered the advancement towards progress, Jadids have noticed unnecessary and useless traditions (excessive ceremonies, magnificent weddings and funerals) spread in everyday life of people of Turkestan, which had nothing to do with Muslim canons, burdening the life of people which was hard. One of 
urgent topics to which lots of articles and reports had been devoted was the the Muslim's ethics. Jadids tried to give answers to such questions as how, what kind of way of life the Moslem should conduct, how to treat people around and other nations and religions, women and children.

Ethics questions were always typical for east philosophy. Within the bounds of Jadidism in the most developed form they found their reflection in Abdulla Avloni's (1878-1934) creativity and first of all in his work "Turki Guliston yohud akhlok" (it is literally "the Turkic flower bed or moral") (Avloni, 1998, p.34).

According to Avloni ethics means first of all, a practical-pedagogical orientation. It is "a science calling people to good achievements and warning them from bad actions", on the basis of proofs and examples it should display what is good and bad and describe good and bad tempers.

Avloni did not see a moral person without education and the prospering future. Therefore he considered various kinds of human activity and human character traits through a prism of ethical categories. So, for him the knowledge and lack of knowledge are not just phenomena of informative activity and the concept of gnoseology. Knowledge "allows us to distinguish unmistakably good from bad, kind from unkind, permitted from prohibited, pure from dirty", while ignorance means "the beginning of bad temper", "egoism and evil". According to Avloni, moral for the Moslem should be based on universal human values, to have a practical orientation and rationally serve to progress. Jadids considered that the people of Turkestan should possess such qualities as tolerance, devotion, bravery, composure, discipline, conscientiousness, justice and to try to overcome such shortcomings as laziness, idleness, egoism etc. The analysis of these categories was carried out by A.Avloni through the questions of education of young generation to meet the society requirements.

So speaking about discipline, A.Avloni considered it not as quality of a certain person, but much wider i.e. from the position of a posture in society. He considered that "the nation development, its spiritual growth, perfection depend mostly on timely and qualitative performance of pursuits and duties confronting people".

The leading part in formation of individual A. Avloni gave to education. From his point of view an individual was created as talented and gifted, capabale of distinguishing good and bad, but these qualities were developed in the course of education in which the important role is played by ethics.

Thus, ethics and moral questions were one of the parts of educational work and were in the spotlight of Jadids. They represented and at the same time were the representatives of "new Muslim ethics" taking the elements of world experience in this field. Trips and dialogues with educators from other regions of the Russian Empire helped them to develop it and many other aspects of progressionists' educational program.

In 1905, Abdurashid Ibragimov, a member of bureau of the Central committee of the Russian Moslems worked in this direction in Tashkent. In 1908 before travelling to Cairo a founder of Jadidism, friend and teacher of M.Bekhbudi Ismail Gasprinskiy visited Turkestan again where he familiarized with the work of Samarkand new method schools. In 1910 a well-known Tatar Jadid Sadri Maksudi travelled all around Turkestan kray (Agzamhodjaev, 2006, p. 40). Tashkent Tashkent, being an administrative and cultural center of Central Asian region, became athe office for meetings of representatives of reformatory movements.

Jadids understood that the colonial system of board of the Russian administration in Turkestan not only fail to meet the national needs, but also causes enormous social and economic harms to the country. Therefore their struggle for new method secular education, strengthening the best parts of national identity, intensive development of culture spilled over into a struggle for political independence and democratic government.

However, educational activity of Jadid movements of initial period was not a campaign of purely cultural enlightenment as the Russian populism's educational activity, it also embraced the issues of raising national consciousness. Educating, Jadids made reference to history of Turan which was a great country in the old days and called to know the European history to emphasize that their country as the part of East had made much for the West.

Jadids were convinced that Turkestan kray, being a part of the Muslim world, but representing an independent unique phenomenon in the world history, was obliged to make good its position in the difficult and contradictory future which was opened in the 20th century.

At this stage they considered education as the most paramount issue and would make decisions furiously which was inherent only in young and hotheads.

Analyzing the age of Jadids, we were convinced that their program aimed at organizing the future of Turkestan reflected youth outlook. By 1910 the age structure of movement participants was from 13 to 36 years and above. 
The head of Jadidism M.Bekhbudi was 36 and A.Chulpan who subsequently became a favourite poet of youth, was 13, F. Khodjayev was 14 at this time. However, none of them made old bones.

\section{Religious-National Tolerance and Ethnic Self-Identification of Jadids in Turkestan}

The Russian Empire invasion into Central Asia and its colonization inconsistently had an influence on life, a mode of life, culture and mentality of its people. Collision of two cultures gave rise to new problems, revealing advantages of European civilizations where bearers were dominating structures and its values was rejected by local people. Economy transformation, pouring of the Russian capital into the region, intensive transformation of Turkestan into raw-materials base inevitably required changes of the conditions of life and legal norms. It was difficult process. B. Babadzhanov said: "such situation caused different (mainly negative) reaction to innovations as the dogmatic and legal system of Islam is constructed in that way that its bearers should give an appropriate assessment to any innovations (bid'a). This innovation can be identified as acceptable i.e. "good" (bid'atun khasanatun) and as unacceptable or doubtful. Also it can be accepted under certain conditions and with reservations"1(Babadzhanov,200,p.13). Speaking more clearly, theological assessment of innovations gained currency which would allow justifying the participation of Moslems in new processes and giving them blessing. For its realization, first of all, formation of the tolerant attitude to other religions was required so long as all innovations were meant, first of all, as introduced by bearers of other religions such as the Christians and the Hebrew.

National progressionists of Turkestan were real mouthpiece of religious tolerance ideas. They had a general authority on it owing to their religious education, outlook and aspirations. The most outstanding representatives graduated not only madrasahs, but also were in holy orders. For example, Makhmudkhodja Bekhbudi was a hereditary mufti and at his time held this position in Samarkand region. Munavvar kary also worked as an imam of Darkhon mosque in Tashkent after graduation from madrasah and Ishak-khan Ibrat carried out duties of kazy in Tura-Kurgan.

Jadids, owning cultural capital of the past, having the possibility to travel, see industrial and cultural achievements of Europe and developed Muslim countries, get acquainted with intellectual people and representatives of various social movements, realized perfectly how much Turkestan had lagged behind and they commenced to support a modernization of Muslim cultural traditions of Central Asia. They began the reforms with understanding of the Islamic doctrine.

The American historian A.Halid considers that "Central Asian Jadidism was directly localized by the limits of Muslim modernism... Its rhetorical structure originated in Muslim tradition of Central Asia and consequently in their own traditions Jadids relied on Islam... Modernity "is attached" to"true" meaning of Islam and only Islam cleared from all amendments, appeared for centuries, could provide well-being of Moslems. Coming to new vision of the world, Jadids came to new realization of Islam i.e. to realize what is to be the Moslem" (Adeeb, 1998, p.113).

In their theory of society updating the important question was to become close friends with Europe which has made great strides in development and borrowing their great achievements. The way out of the crisis caused by colonial position of Turkestan was found, first of all, in cultural reforms with European experience application. To achieve the goal, firstly, the working out of the legitimization theory of progress by Islam was required and the concepts about the attitude of Islam to the problem of harmonious development of man and society. Jadids tried to realize this idea through literary and journalistic creativity. The important place in this concept was the theme of tolerance: religious and national. These points were seen in the works of Jadids. In the books of Abdurauf Fitrat (Fitrat,200,pp.46-98). "Munozara" and "Indian traveler's stories" two foreigners introduced themselves as competent experts of the Koran and in the name of two foreigners the author appraises the situation concerning education, management, army, social and economic life of Turkestan and Bukhara. There is a supposition that A. Fitrat chose knowingly Frenchman in his first work and Hindu in the second i.e. one European and one Moslem, but not Central Asian, speaking in the name of foreigners about the objective reasons of progress and ayahs of the Koran, calling to it.

A Frenchman marks the universal importance of the Koran and hadis with the following words: "We are people of other religion, but we haven't burned the Koran, we have used it at our interests, have studied to satisfy the thirst for knowledge. We read it which was specified in it and quickly achieved progress. And you, being unable to use its precepts, have come to the crisis". Thereby A.Fitrat points out that Moslems should learn to respect other religions as European progressionists do in relation to Islam.

"And if the Christian books devoted to a science and inventions, are sinful, then how we will develop without reading them and how we will defend ourselves, but the Koran names sacred books - the Bible, Talmud and Zabur", 
- A.Fitrat exclaims, rejecting thereby religious nihilism and Muslim limitedness. Moreover, he quite often referred to the Christianity history, in particular, the inquisition period, to show what the clergy's appropriation of secular arm and boundless belief in its innocence will lead to. It was rather courageous reasoning calling not to idealize the clergy. According to the author, the majority of them in Bukhara, commit crimes to the flock: "the situation of Bukhara and Bukhara population is lamentable and impious actions of your ulama is the reason of a spiritual nonexistence of this nation (Rauf, 1913, p.27). Telling about how European people had overcome a church absolute power by means of Protestant societies, he led a reader to thoughts that the clergy can't be assigned as legislators and masters of destinies and it is impossible to follow blindfold for instructions. Thus, he supported democratization of spiritual sphere and was against its monopolization by religious figures.

In order to confirm once again the loyalty in relation to other cultures and religions, especially non-Muslim, Jadids often referred to the history of Europe and Asia. As the main tool in propagandizing of tolerance was the theory of continuity of cultures, interrelation, intertransmission and interpenetration over a period of long historical development. For progressionists the history was a major tool of propagandizing their ideas. Historical works of Jadids include a large quantity of publications that are subjected to be thoroughly studied. First acquaintance with such works as "Taraqqiy va tanqid" ("Development and criticism"), "Istambul" ("Istanbul"), "Mukhtasari tarikhi islom" ("Short history of Islam") by A.Fitrat; "Uz hollarimiz" ("Our situation") by Mirza kary; "Tarikhi Fargona" ("History of Fergana"), "Tarikhi madaniyat" ("Cultural history"), "Mezon ul zamon" ("Time Criterion") by Ishak-khan Ibrat; "Mirzo Ulugbek" "Bukhoro" by M.Bekhbudi; "Bukhoro inqilobi tarikhi uchun materiallar" ("Materials for history of Bukhara revolution") by S.Aini; "Turmush urinishlari" ("Problems of Life") by M.Mukhammadzhonov (the last one is devoted to the history of Jadidism) allow us to understand that to explain the current situation Jadids leaned on the history. Especially it can be seen in M.Bekhbudi's and A.Fitrat's works. A.Fitrat, following Farabi, Ibn Sino and Beruni in his work "Nazhot yuli" ("Liberation guide") made an attempt to connect all secular sciences with Islam. Therewith secular sciences covered European achievements as well. In this book A.Fitrat speaks against religious intolerance: "There is no doubt that though people practise various religions and live in different countries, belong to various tribes and nations, but all of them are children of one father and from the same mankind. In other words, they are siblings. If so then all of them should be merciful and love each other" (Fitrat, 2001, p.159). The thoughts that Europe borrowed achievements from the fields of agriculture, crafts, arts, science and knowledge of Central Asia in the period of the Muslim Renaissance are clearly observed in "Munozara" which was mentioned above.

Understanding that the time of reverse borrowing came A.Fitrat writes: "to our great misfortune, if we make a single step to return our culture and civilization lost then our ulemas immediately will say: "You became a kaffir" and they start to disturb us".

Jadids were depressed by ignorance, especially, in the field of medicine. Many Moslems, being scared of the clergy could not turn to Russian doctors. Therefore A.Fitrat and other authors convinced people that it did not contradict the Sheriat. A.Fitrat demonstrated by such example: "Abbasid Caliphs... employed lots of physicians and scientists with other religions, made them translate scientific Greek and Indian books into Arabic and ordered to study them in Baghdad madrasahs. The Caliph Abu-Jafar-Mansur-Abbasid during the time when Great Imam (Abu-Khanifa) lived, appointed George Bakhtishu of Christian religion as a head of physicians of Bagdad and Caliph Abdurashid, ... assigned aforementioned George's son (Christian) as a head physician of Baghdad and appointed Mank, a fire worshipper as a personal physician. It all proves that if now we, Moslems, will send some people to Europe to study medicine and therefrom we will invite experienced doctors and we will appoint them as teachers in medical madrasahs and all of these will not contradict the Sheriat".

The work of Iskhak-khan Ibrat "Mizan az zaman" written in the same didactic style, where he proves theologically the necessity of use of European civilization, technological and cultural innovations. However, if A.Fitrat uses his literary possibilities for this, constructing his own version based on the interests of reader to the form of story and I.Ibrat uses the form of concrete sermon "amri maruf". As B.Babadzhanov writes: "Ibrat realized well and quite reasonably that the only way to change conservatism of society is to speak with the fellow citizens in plain language taking into account their religiousness" (Iskhak-khan tura, 2001, p. 6). For this reason he chose the sermon. As well as others, I.Ibrat sets his choice on two important subjects: consent and unity and the attitude to non-Moslems, drawing carefully the idea of tolerance by the Koran and hadis. His call to tolerance is based on a well-known legend about a common ancestry i.e. from one father, Adam and one mother, Eve. Among Jadids Iskhak-khan Dzhunaidullah Ibrat was, perhaps, the most effective supporter of inculcation of the western culture. He lived abroad, visited Kashgar, Istanbul, Sofia, Athenes, Rome, Kabul and Jidda. From 1892 to 1896 lived in Bombay and Calcutta where he studied not only Urdu, but also English, French languages, Ancient Phoenician, Hebrew, Syrian and Ancient Greek written languages and he knew Russian perfectly and was good at Russian 
literature. This knowledge and many-sided talent and good knowledge of the world literature allowed him to make the first and unique Uzbek-Arabic-Persian-Turkish-Indian-Russian dictionary in 2 volumes which was called "Lugati sitta al-sina" (Ibrat, 1999, p.13).

Jadids had been frequently reproached that they worshipped the West, but this "drawback" determined their tolerance. They could not help admiring the achievements of Europe while Turkestan society was backward in development.

A negative attitude towards new things and kinds of communications were called as fanaticism and they brought from abroad innovations (record players, cameras, lamps, etc.). They gave reasons for arguments that during the period of the Prophet there were not so many things which had later become the necessaries of life. The dweller of Bukhara, from A.Fitrat's "Munozara", discussing about harmfulness for Moslems at Jadid schools, he as an example named armchairs and chairs contrived by the Christians on which children sit. A.Fitrat on behalf of a Frenchman concluded that God would accept ayahs that were read with feeling and sincerity, sitting in the armchair rather than on a muddy straw.

In opinion of Jadids, religious conservatism prevents from using innovations resulting in crafts and enterprises lag, failing to withstand the competition with the Russian developed industry.

Thus progressionists successfully combined "traditional (theological) mentality with the ideas of having technical and scientific revolution in Muslim societies of the East with appeals to be more open and tolerant" (Babadzhanov, p.12).

However, it did not have them see and scrutinize a national and religious policy of tsarism in Turkestan infringing upon indigenous population's interests, hindering to develop the culture and education adequately (the authorities' encouragement of the Christian-missionary activities, interdictions of Jadid schools and newspapers can be an example). Jadids understood perfectly that the tsarist administration wasn't interested in activization of Moslems and growth of their political consciousness.

But the efforts of the tsarist administration directed to isolation of Turkestan from the influence of political processes, befalling in Russia, Asian and European countries were unsuccessful.

Tolerance of national progressionists had strongly developed thanks to their cooperation and relations with like-minded persons from other Muslim regions of Russia, which, in its turn, had been closely connected with the Russian democratic movement.

Ideological views of Turkestan Jadids were in many respects modified under the influence of ideological and political currents penetrating into the kray from neighboring countries, because of democratic movement integration" (Abdullayev, 1999, p.75).

Jadids took a sober view of the future of Turkestan and did not define the global goal to be independent of Russia, realizing inequality of power and situations, but at the same time they asserted Moslems rights to participate in government management. Especially this situation was displayed after the February Revolution when they believed that Turkestan could possess the equal rights in Federal Russia. However, in their opinion, an essential condition for that was mutual respect, religious and national tolerance of both parties. Mahmudkhodja Bekhbudi, who was a main ideologist of Jadidism, at the time of sharp debate concerning the public management form in Turkestan and indigenous population's participation in elected bodies in April, 1917, said: "It is incorrect to say that Moslems are backward and fanatical. We have known little about each other and have lived together little and only freedom will unite us. The unification of this kind is in Moslems' interests, who wish to study from elder Russian brothers. We are children of Russia and should go ahead together, previous incoveniences are to be forgotten".

If at the first stage of movement development progressionists' main purpose was to unite Moslems embodying democratic forces then by 1917 these ideas went beyond the scope of internal unity. The sovereignty condition of Turkestan as a part of Russia was to unite all forces regardless of religious and national identity. M.Bekhbudi wrote that the laws are to be issued in the new state that would protect the rights of all Turkestan population, irrespective of religious and racial identity (Bekhbudi, 1917).

Tolerance, toleration and friendly relation to all people received a particular display in the highest political activity of Jadids, expressed in the idea of creating a national-territorial autonomy of Turkiston Mukhtoriyati. As we mentioned above, it was the first attempt of the national-state establishment based on general humanistic ideas of the world experience. 
At the second Regional Muslim congress (September 7-11, 1917), convened on an initiative of Jadid party "Shuroi Islomiya", the resolution was passed, it says: "the congress opposes the surrender of power to Councils of soldier's, working and rural deputies. The authority is to be coalition and rely on all forces of the country i.e. national". Unlike Bolshevik, the power of Turkiston Mukhtoriyati was really representative and tolerant. The number of Turkestan Provisional Council was 32 which was determined by the quantity of earlier delegated deputies from Turkestan kray into All-Russian constituent assembly. The National Assembly (Millat Mazhlisi) consisted of 54 seats, 4 of them were assumed to give municipalities to the representatives of Congress and 18 seats to the representatives of different krai European organizations. It means that one-third seats were given to the European part of the population which relative density at that time did not exceed $7 \%$ of total number of inhabitants of Turkestan (Agzamkhojaev, 1996, p.32) .

On December 1, 1917 the Provisional Government of Turkistan Mukhtoriyati distributed leaflets with the appeal to the population of Turkestan krai where it was said: "Extraordinary krai All-Moslem congress urges all citizens of Turkestan - Moslems, Russians, Jews, workers, soldiers and peasants, all tribes and nations, municipial and Zemstvo self-governments, political and professional bodies and unions, all public and private institutions that exist in the kray to rally round Turkestan popular rule and help to realize the difficult tasks entrusted to it" (Reports of provisional government of Autonomy Turkestan, 1917).

By this time religious and national tolerance of progressionists had merged in one concept, having received a state policy status.

However, tolerance of Jadids did not prevent them from attaching priority importance to the Islamic culture. They always marked Moslems' participation in the world civilization attainments. Using the works of Aristotle, Platon and Socrates extensively and having first-hand knowledge of modern philosophical trends (Prilutski, 1999, p.62), they kept finding points of contact with an Islamic east philosophy. They stood pat on world outlook principles of intercultural dialogue. They considered that the West and the East are compatible, when they carry on dialogue on equal grounds. The reasons for that were probably not only modern processes and education. Religious tolerance, as a matter of fact, in Central Asia had historical roots. Throughout many centuries members of different denominational backgrounds and ethnos peacefully coexisted here. Therefore in conscious of the most progressive part of society there were feelings of religious toleration and benevolent attitude towards people irrespective of their racial and religious background.

It enabled Jadids following Young Turks and Egyptian reformers to turn to Europeans' political experience preserving its national identity and originality. Step by step they had the formation of views regarding a correlation level of European and the East (Islamic) principles of society - "from constitutional monarchy, shariah and fragmental employment of local government to "extended" convergence approach", that set coexistence of Islamic norms with the public democratic system.

The ethnic issue in Jadids's program was solved within the unification of all ethnos. May be it was rather primitive. But their nationalism was closely connected with ethnic concepts. They expressed ethnic feeling with such terms as "Millat" (Nation), "Musulmonlar" (Moslems), "Turkistonliklar" (Turkestan population) and "Turonliklar" (Turan followers). "Millat" by their understanding means Turkic speaking and Iran speaking people inhabited Turkestan, Bukhara and Khiva khanates. "Moslem" is used for all coreligionists and it has not only a religious shade but it reflects the concept of Turkic speaking and Persian speaking population of Turkestan. When Jadids spoke about association of Moslems, of course, they meant not religious consolidation but ethnic. As is obvious from the passage of M.Bekhbudi's article called "Bayoni Haqiqat" where along with ethnic terms as "Russian" and "Jews" the term "Moslems" is used.

At the same time the word "Moslems" is applied as a religious characteristic together with the term "Christians". We can say that because of Jadidism the transformation of a religious concept of Moslem was befallen into ethnic. Political ideas and consolidation of progressive forces, being a key condition of successful struggle against colonialism, led to ethnic consolidation.

It has concern not only with Central Asian Moslems. D.M.Iskhakov wrote, researcher of Tatar Jadidism, "ethnic consciousness of Tatars up to the middle of 19th century "was wrapped up" in a "Muslim" cover and confessionim "Moslems" was considered rather strong" (Iskhakov,1997, p.49). Shamil Ogly, American historian considers that Tatars did not want to call themselves with this name thinking that their condition is defective and being constantly insulted from Russians and consequently preferred to call themselves as Moslems (Shamilogly, 1990, p.24).The same situation happened with Sarts.

Indicative of the fact that ethnic matters were also linked with anticolonial struggle by Jadids was confirmed in M.Bekhbudi's article "Sart suzi majkhuldir" ("the Word of Sarts is unknown") that became popular among 
intelligency, which is an important source, unfortunately, to little known historians and ethnographers till now, whom we will talk about later (Bekhbudi, 1914, p.340).

In the second article "Qozoq qarindoshlarimizga ochiq khat" ("Open letter for Kazakh brothers") M.Bekhbudi wrote: "We are, Kirghizs, Kazakhs, Uzbeks, Turkmens, Arabs, Persians, in general all Moslems living in Turkestan, Kazakhstan and Turkmenistan and other nations as Jews and Christians being joined, should establish an autonomy (Turkestan Autonomy established by Jadids in Kokand in 1917 under the direction of the Russian Federation) and strengthen it.

If we want to live according to our own free will, the Sheriat and customs, we should dismiss temporary disagreements, haughtiness and arrogance and forget everything for the sake of an autonomy" (Bekhbudi, 1918).

The ideas of unification under Turkism of Central Asian Jadids were not new and transcend the krai. From our point of view, the influence of Russian Jadidism, in particular, Tatar, was strong. In materials of "a special meeting" at the Ministry of Internal Affairs of the Russian Empire in 1910 it was said that "Kazan progressive Tatars make great efforts to unite Russian Moslems referring to religious imaginary tribal unity in one nation with one artificial Turkic-Tatar language" (Iskhakov,1993, p.24). As is officially reported by the Kazan governor the intelligency "is saturated with religious-national autonomy within the country and with the aspiration to Pan-Islamic and Pan-Turkism unity". The same kind of official information was sent to the empire's top central management of Turkestan general governors and Turkestan district security department respectively.

As stated above, a constitutional movement in Iran (1905-1911), anticolonial actions in India (1905-1908), a revolution in Turkey (1908) and others had a determining influence on national movements in Turkestan and events in the East. However, Jadids of Turkestan never aimed at establishing a general Turkic or a general Islamic state. The integration motto bore spiritual-moral character and was against the tsarist autocracy and bore anticolonial character.

In 20th years of the XX century, during the Soviet power period, when a majority of Jadids emigrated after defeat of the Turkestan Autonomy in Kokand and those who left started working in education, the idea of Turkism still continues to develop. It was expressed in Turar Ryskulov's position, a chairman of Turkic General Executive Committee, who in January, 1920 supported the idea of establishing the Turkestan Soviet republic which would unite the Turkic people. His position was directed to fight against the dominance of totalitarian center, he thought that the Turkic republic establishment will enable for sovereign national development under the protection of the Russian Federation. However, T.Ryskulov's idea did not suit Bolsheviks and was refused by Vladimir Lenin. The Turkestan Autonomous Soviet republic had practically no rights and its legislative authority was subtituted for central party bodies (Turkestan in the early 20th century,2000.pp.155-163).After the national territorial demarcation of Central Asia and the national republics establishment, a majority of Jadids, followers of "Turkism" idea started living in Uzbekistan calling themselves Uzbeks and working in the sphere of Uzbek culture.

\section{Conclusion}

This is a potted history of Jadidism and the end of it was tragic. In the Soviet historiography it was estimated as bourgeois movement, "corrupting a consciousness of the mass by nationalism ideas and leading them away from revolutionary struggle (Note 2) (The History of Philosophy, 1961, pp.385-386) and Jadids were put to the repressions and annihilation. Jadidism was destroyed by Bolsheviks because the concept of national-state formation and society's breaking of colonialism deadlocks was serious alternative to the totalitarian Soviet system and threatened its downfall. But, despite the sad end, a national-progressive movement founded by Jadids, favoured the development of national self-consciousness, has played an essential role in formation and development of national liberation ideology. Its enduring value is that it had forced to wake up and rouse the fallen asleep East, to remember freedom, national pride, great ancestors, rich culture and others that were consigned to oblivion by colonialism. Their doctrine was true because it carried away all progressive and thinking youth and not only youth. Their actions program became a model for the future generations. A doubtless historical merit of Jadids was their attempts to reform a society starting from the smallest i.e. education and its development was considered the most important thing for progress. Their attempt of political reforms was a striking illustration of conceptual development of their ideas and as for failures as a result of cataclysms in the world to which Turkestan was involved in the XX-th century.

Their motto was "not to withdraw within the national bounds and at the same time a vast patriotism and love for the krai, a desire to come out certainly of a crisis" led towards smart of rash actions. Not idealizing, but rather objectively taking up the history of Jadidism, we unequivocally evaluate it as an intellectual phenomenon of the East. The idea of the world experience usage that compressed the best achievements of the East and the West, in our opinion, was the most valuable in the concept of developed society of Jadids. 
The problems of today are Jadid views on religion, mutual relations of old and young generations, their attitudes towards democracy, development of culture of Turkestan, their reverent attitude to knowledge, as a key condition of country's well-being.

Unfortunately, no archival documents from Jadids left. The unique material that makes possible to judge their way of thinking and vital activities are their works, newspapers and magazines they used to publish and eyewitnesses' rare recollections. Memoirs of Munavvar kary, written when he was imprisoned, are very valuable, but they have to be considered with regard to the conditions in which they were written. And as to archival documents of tsarist secret political police i.e. reports of agents, officials, opinion letters of departments etc. of course, they provide a good deal of information. But they are one-sided accounts and policy-induced. Therefore, the method of comparative analysis applied in studying of this issue is rather correct and effective.

\section{References}

Abdullayev, R. (1999). Integratsionnye protsessy v musulmanskom mire i turkestanskie djadidy // Jadidchilik: islokhot, yangilanish, mustakillik va tarakkiyot uchun kurash. Tashkent: Universitet, 75.

Adeeb, K. (1998). The Politics of Muslim Cultural Reform. Jadidism in Central Asia. Berkley-Los-Angeles-London, 113.

Agzamkhodjayev, S. (1996). Iz istorii borby za avtonomiyu Turkestana // Turkiston mustakilligi va birligi uchun kurash sakhifalaridan. Tashkent: Fan, 32.

Agzamkhodjayev, S. (2006). Istoriya Turkestanskoi Avtonomii (Turkiston Mukhtoriyati), Tashkent. Tashkent Islam University, 40.

Avloni, A. (1998). Turkiy Guliston yokhud akhloq // Tanlangan asarlar, Vol. 2. Tashkent: Manaviyat, 34.

Babadzhanov, B. (2001). Predislovie k knige Iskhak-khan tura ibn Djunaidallah Khadja. Mizan Az-Zaman. Tashkent-Tokyo, 13.

Babadzhanov, B. Predislovie k knige Iskhak-khan tura ibn Djunaidallah Khadja, 12.

Bekhbudi, M. (1914). Sart suzi majkhuldir // Oina. No. 22, 340.

Bekhbudi, M. (1917). Bayoni khaqikat. Ulug Turkiston, 12 June.

Bekhbudi, M. (1918). Qozoq qarindoshlarimizga ochiq khat // Hurriyat, 26 January.

Bendrikov, K. (1960). Ocherki po istorii narodnogo obrazovaniya v Turkestane (1865-1992). Moscow, 260.

Central state Archive of the Republic of Uzbekistan, ph. И-47, 1. list, document 955, 230.

Fitrat, A. (2000). Khindistonda bir farangi ila Bukhoroli mudarrisning jadid maktablari khususida qilgan munozarasi // Tanlangan asarlar, Tashkent, Manaviyat, 46-98.

Fitrat, A. (2001). Nazhot yuli (Rakhbari nazhot), translated by Sh. Bokhidov, Tashkent: Sharq, 159.

Gafarov, N. (2000). Istoriya kulturno-prosvetitelskoi deyatelnosti jadidov v Bukharskom emirate (the beginning of the 20th century), Khuzhand. 73.

Historigraphy of social sciences in Uzbekstan. (1974). Bibliographical essays, Tashkent: Fan, 164.

Ibrat, A. (1999). Sufizoda, Selected Works. Tashkent: Manaviyat, 13.

Iskhak-khan tura Ibn Junaidullah Ibrat. (2001). Mizan Az-Zaman, Tashkent-Tokyo, 6.

Iskhakov, D. (1997). Phenomen tatarskogo jadidizma: Introduction to Sociocultural comprehension. Kazan, p. 49.

Iskhakov, M. (1993). Formirovanienatsionalnogo samosoznaniya tatar: problema stanovleniya (1 $8^{\text {th }}$ century till the early $20^{\text {th }}$ century), Kultura, iskusstvo tatarskogo naroda. Kazan, 124.

Kayumov, M. (2005). Obshestvenno-politicheskie protsesy $v$ Khivinskom khanstve (the second half of 19th and early 20th centuries). Scientific paper dissertation, Tashkent. 15.

Khudaikulov, A. (1995). Prosvetitelskaya deyatelnost jadidov Turkestana (late 19th and early 20th centuries). Dissertation on historical sciences, Tashkent, 78.

Klimovich, L. (1936). Islam v tsarskoi Rosii, Moscow, 214-215.

National Economy of Turkestan, March 30 - May 18th, 1918. 
Polvonov, N. (2005). Khorazmdagi izhtimoyi kharakatlar va siyosiy partiyalar tarikhi (1900-1924). Scientific paper dissertation on history. Tashkent. 15.

Prilutski, E. (1999). Zapad i Vostok v filosofii i teoreticheskikh kontseptsiyakh jadidov // Jadidchilik: islokhot, yangilanish, mustakillik va tarakkiyot uchun kurash, Tashkent: Universitet, 62.

Pyaskovski, A. (1958). Revolyutsiya 1905-1917 v Turkestane. Moscow.

Rauf, A. (1913). Rasskazy indiyskogo puteshestvennika. Samarkand, 27.

Red Archive, Moscow. (1929). Vol. 34, 54.

Reports of provisional government of Autonomy Turkestan. (1917). 13 December.

Rizobadli, T. (1915). Idoraga maktublar // Sadoi Turkiston, No. 64, 4.

Shamilogly, U. (1990). The formation of Tatar historical consiosness: Sihatndolin Marcanianal image of the Golden Horde. Central Asia surver, 9(2), 24

The History of Philosophy. (1961). Vol. 5, Moscow, 385-386.

Turkestan in the early 20th century: To history of sources of national independence. (2000). Tashkent, 155-163.

Zenkovsкy, S. (1967). Pan-Turkism and Islam in Russia. Cambridge Massachusetts: Harward University Press, 88.

\section{Notes}

Note 1. Some author's editorships of this work written in 1875-1881 and enjoying a wide popularity among progressive-minded people of Bukhara and Turkestan are known. As historian B.V.Lunin wrote: "Manuscript copies passed through many hands, giving to readers answers to many questions of modern socail life broadening their general outlook", Istorografiya obshestvennyh nauk v Uzbekistane (Historiography of social sciences in Uzbekistan). Bibliographical essays. Tashkent: Fan, 1974. p.164.

Note 2. The following extract can be served as a standard example of assessment of Jadidism in the Soviet period: "Jadidism caused damage to the development of advanced public thought in Kazakhstan and Central Asia have a disastrous impact on many representatives of democratic ideology which owing to social and economic backwardness of Kazakhstan and Central Asia could not sort out class features of this reactionary bourgeois-nationalist ideology". Istoriya filosofii. V. 5, Moscow: 1961, p. 385-386. (35) 